\title{
現地観測に基づく水俣湾の流動特性 に関する研究 \\ SEASONAL BEHAVIOR ON TIDAL CURRENT \\ BY USING IN SITU MEASUREMENT DATA IN THE MINAMATA BAY
}

\author{
多田 彰秀 1 - 栁瀬 夏樹 2 - 矢野 真一郎 3 \\ 中村 武弘 4 ・押川 英夫 5 ・赤木 洋勝 6 \\ Akihide TADA, Natsuki YANASE, Shinichiro YANO, \\ Takehiro NAKAMURA, Hideo OSHIKAWA and Hirokatsu AKAGI

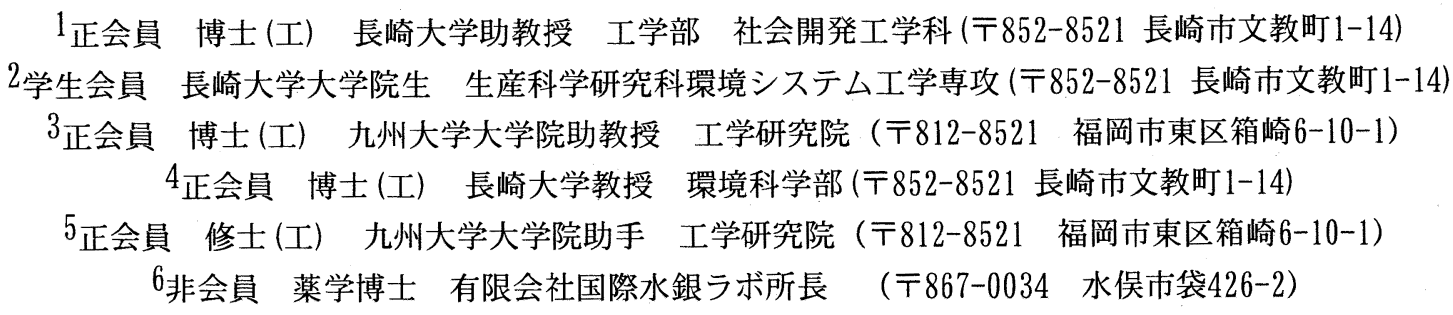

In the Minamata Bay, the remediation project on water and bottom sediment environment was completed in 1990. About 0.8 million $\mathrm{m}^{3}$ of bottom sediment contaminated by mercury was dredged. However, a recent measurement of mercury in the sediments [Tomiyasu et al.,2000] has shown that mercury is spreading around the center and southern parts of the Yatsushiro Sea from the Minamata Bay. Although the concentration of mercury in bottom sediment is lower nowadays $(<10 \mathrm{ppm})$, modelling for accurate prediction of mercury dynamics is necessary. In order to predict the mercury dynamics accurately in a coastal area, it is necessary to measure mercury transport in an actual sea.

Thus, the current observation by using ADCP (RD Instruments Workhorse 1,200kHz), which was mounted on the side of a fishing boat, was performed on the 2nd of December, 2002 and the 29th of July, 2003 to realize a three-dimensional structure of tidal current in the Minamata Bay. As a result, it was found that a horizontal circulation flow occurred during ebb tide in summer.

Key Words: Minamata Bay, in situ measurement, tidal current, mercury transport, thermal stratification, Acoustic Doppler Current Profiler

\section{1.はじめに}

1950年代後半，化学工場から排出されたメチル水銀が 原因で発症した「水俣病」（中毒性の神経疾患であり, 公害病として認定）によって多くの犠牲者がでたことは 周知の事実である. その舞台となった水俣湾では, 1981 年から1990年の間に実施された環境修復事業によって, 現在では安全宣言が出されている. しかし, 未浚渫海域 （袋浦）および浚渫海域においても未だに微量な水銀が 残留しており, 水俣湾から八代海東岸沿いに拡がってい ることが報告されている11,2).

微量水銀が底質粒子に吸着し潮夘や波浪などで輸送さ
れるしした仮定の下での底質の移流・公散モデルによる 将来の八代海流出状況を正確に予測するためには, (1)底 質輸送構造の把握, (2)残留水銀の溶存態と懸濁態との割 合の解明, (3)塩分濃度, 溶存酸素濃度および有機物量な どのメチル化への影響評価, (4)流動・物質輸送および底 質移動の高精度なシミュレーターの開発などが必要不可 欠である.

本研究では，上述の(1)を最終目標とし，その第一段階 として, 水俣湾内の流動特性を解明するため, 2002年の 冬季および2003年夏季の大潮期に実施したADCPによる曳 航観測および多項目水質計による成層調査の結果につい て報告する. 


\section{2. 現地観測の概要}

3つの湾口を有する水俣湾の流動特性を解明する目的 で，現地観測を2002年12月2日 (大潮期) と2003年7月29日 (大潮期)に実施した. 現地観測は，ADCPを用いた曳航観 測と多項目水質計による成層調査から構成されている. すなわち, ADCPを用いた曳航観測では，ADCP (WorkhorseADCP1200kHz，RD Instrument社製) を船の舫側に取り付 け，事前に設定した観測線下の鉛直断面内流況を計測し た. さらに，多項目水質計 (ACL1183-PDK，アレック電子 社製）を用いた成層調査を同時に行っている. なお，水 俣湾内の観測線および観測点位置の概略は図-1に示すと おりである. 冬季の観測では，午前 $6: 00$ か 60 分間隔 で 1 潮汐間に12回の観測を行った (図-2の上図参照 : 図 中の○印は観測開始時刻) 。とくに, 湾口部からの流 入・流出状況を把握するため, 曳航観測では観測線をM1, M-9, M-10およびM-11の4測線とした. 一方, 夏季の曳 航観測では, 成層期における水俣湾内の流動特性の把握 を対象としたため，測線M-1〜M-10およびF-1を2隻の観 測船で分担して計測した．図-2の中図に示すように，観 測開始時 $(7: 35)$ から, 180分間隔で1潮汐間に4回の計測 を行った. また, 冬季および夏季ともに曳航観測と並行 して観測点 $\mathrm{a} \sim \mathrm{i}$ で成層調査を実施し, 水温, 塩分濃度, pHおよび濁度等の鉛直分布をも計測した.

\section{ADCPを用いた曳航観測の結果および考察}

\section{(1) 冬季観測の結果}

\section{a）表層における流速べクトルの平面分布}

図-3は，冬季に観測された表層（水深 $2 \sim 3 \mathrm{~m}$ ）の流速 ベクトルを平面的にプロットしたものである. 満潮時に 対応する 2回目の結果 (図-3 (a)) に着月すると, 北側湾 口の観測線M-9から水俣湾へ流入する流れが認められる. また，下げ潮最強時の5回目 (図-3 (b) ) では，M-9および 袋浦との境界となっている測線M-10から水俣湾へ流入す る流れと西側湾口の測線M-1から八代海に流出する西向 きの流れが確認できる. さらに, M-1の表層部に見られ る西向きの流れは, 干潮時 (図-3 (c) ) から上げ潮最強時 (図-3 (d)) へと継続して発生していることが分かる.

\section{b) 流速ベクトルの鉛直分布}

図-4は，測線い-1およびM-9上で計測された流速べクト ルの鉛直分布を示したものである. 横軸は測線上での航 行距離, 縦軸は水深である. 満潮時の表層で見られた水 俣湾へ流入する南東への流れ（図-3 (a) 参照) は, M-9の ほぼ全断面で発生していることが図-4 (a) より分かる. また，図-4 (b) および図-4 (c) からは，表層（水深2. 60m 〜4. $60 \mathrm{~m}$ ）に西向きの流れが卓越していることが確認さ れる，八代海周辺では，干潮時から上げ潮最強時にかけ

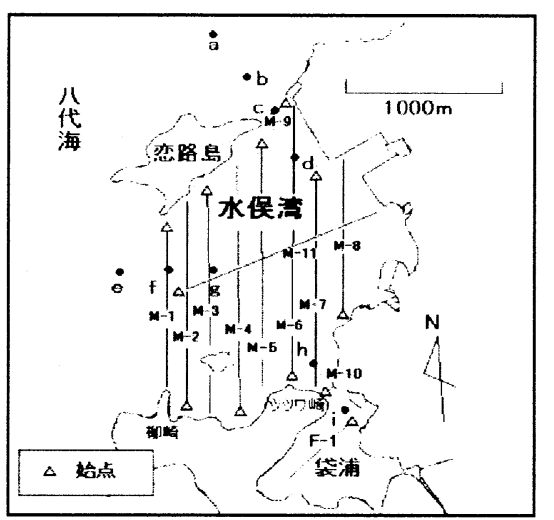

図-1 水俣湾の概要図
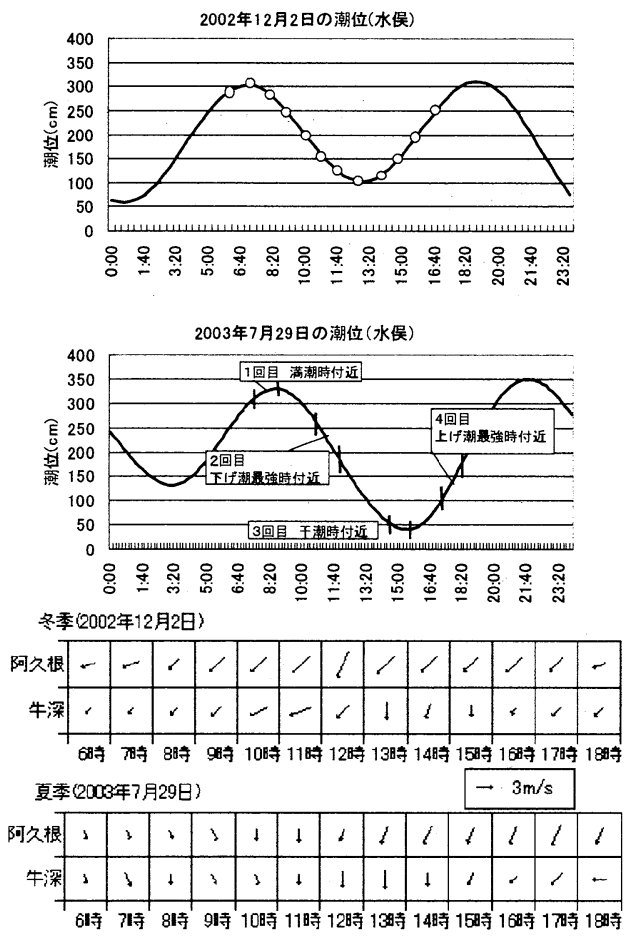

図-2 観測日の潮位図 ${ }^{3)}$ と風速ベクトル図4)

て北東の風 (2〜 3m/s) が約 4 時間程度連吹 (図-2下図参照) していたため，その影響を受けたものと推測される。 な お, 図-4 (c)の上げ潮最強時には, 水深6. $60 \mathrm{~m}$ 付近を境に 流れが逆転しており，それより深い部分では潮汐に起因 する流れが卓越していることも認められる.

\section{c）湾口部を通過する流量の時間的変化}

図-5は，西側湾口 $(M-1)$, 北側湾口 $(M-9)$ および南側湾 口 (M-10) をそれぞれ通過する流量（観測線の法線方向の 流量）の時間的変化を棒グラブで示している. 図中のQ1, Q9，Q10は，それぞれ測線M-1，M-9およびM-10の断面通過 流量である.これらの值が正の場合には, 水俣湾内に海水 が流入することを表している. 湾口部を通過する流量の 算定に際しては, ADCPより得られた流速成分から水深 $1 \mathrm{~m}$ 毎の平均流速を求めるとともに，その值に各観測線上の 水深1m毎の断面積を乗じて求めた. また, 図中には湾口 部を通じて水俣湾に流入する全流量 $(Q 1+Q 9+Q 10)$ の 1 潮汐間の変化が実線 $(-\boldsymbol{\Delta}-)$ で併記されており, 潮汐 




(a) 2回目 (満潮時 : 6時58分〜 7時45分)



(b) 5 回目 (下げ潮最強時 : 9時59分〜10時44分)

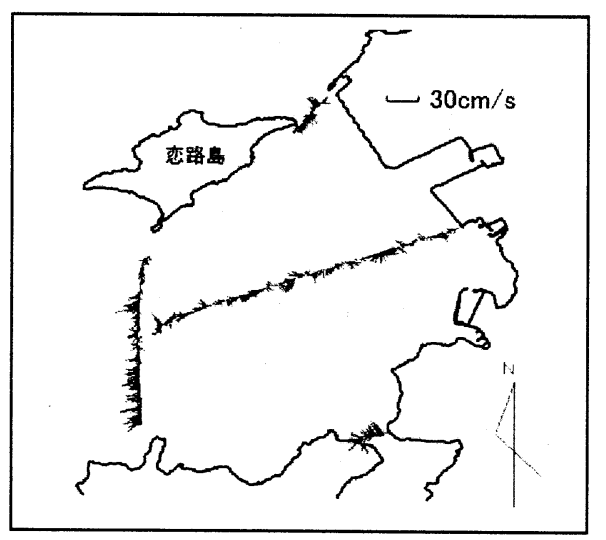

(c) 8 回目 (干潮時：13時2分〜13時48分)

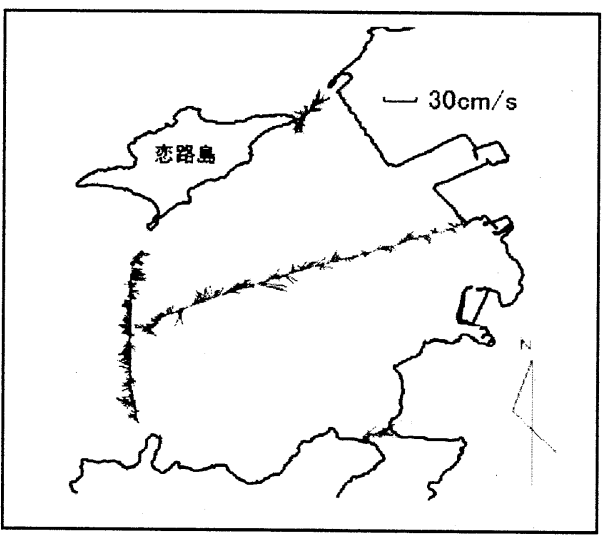

(d) 11 回目 (上げ潮最強時：16時02分〜16時46分)

図-3 冬季観測から得られた流速ベクトルの平面分布 (表層)
の運動に追随していることが窥える.さらに, 西䚋湾口 M-1を通過する流量Q1は他の湾口の流量より大きく, 水 俣湾における海水の流出・流入に関して西側湾口が支配 的であると断言できる. 一方, 北側湾口の通過流量Q9は 満潮時 (2回目観測) から流入傾向が顕著になるものの, 潮位の低下とともに減少しながら，その傾向が少なくと も下げ潮の時間帯継続していることも分かる.

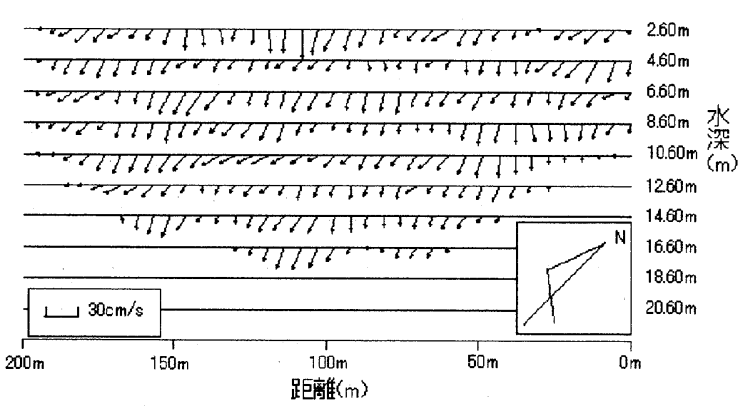

(a) 2 回目 (満潮時) 観測線M-9



(b) 8 回目 (干潮時) 観測線M-1



(c) 11 回目 (上げ潮最強時) 観測線M-1

図-4 流速べクトルの鈶直分布

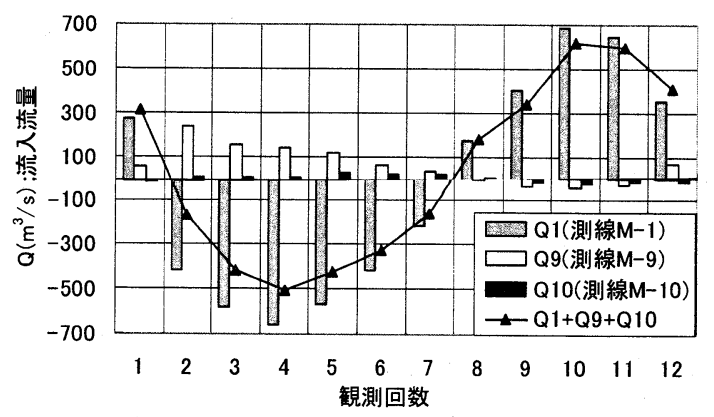

$Q>0$;水俣湾内人流入、Q<0;水俣湾より流出

図-5 湾口部の通過流量とその合計の時間変化 




(a) 1 回目観測 (満潮時付近 : 7時37分～8時46分)

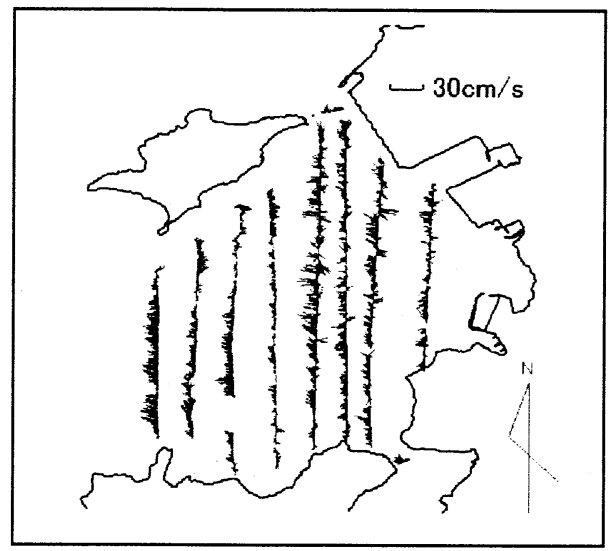

(c) 3 回目 (干潮時付近：14時37分 15時33分)

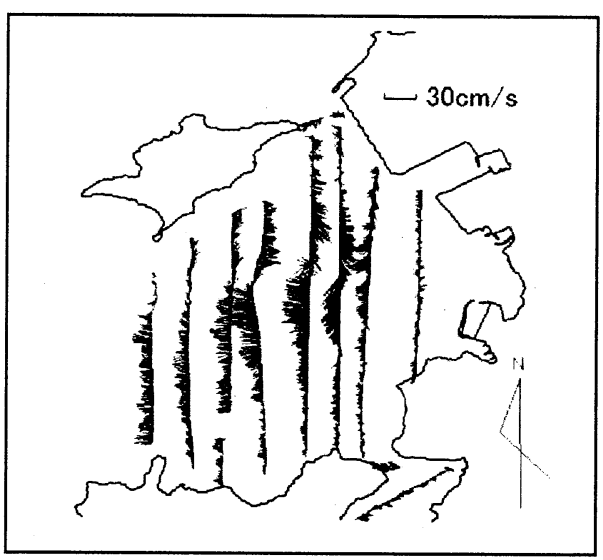

(b) 2 回目観測 (下げ潮最強時付近：10時37分〜11時49分)

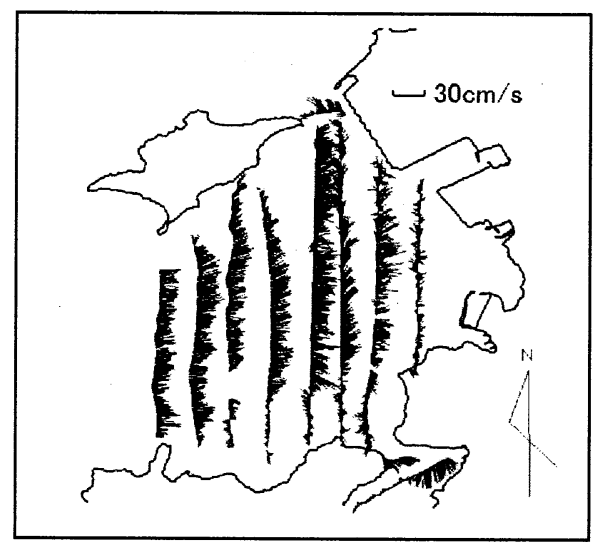

(d) 4 回目観測 (上げ潮最強時付近：17時17分〜 18時26分)

図-6 夏季観測から得られた流速べクトルの平面分布（表層）

\section{（2）夏季観測の結果}

\section{a）表層における流速ベクトルの平面分布}

図一6は，夏季にADCPを用いて計測された表層（水深2 〜3m）の流速べクトルを平面的にプロットしたもので ある. 満潮時に対応する1回目の流れ（図-6 (a) 参照) で は, 北側湾口の測線M-9および測線U-6の北側において八 代海から海水の流入が認められる．さらに，その影響が 袋浦への流入とツツワ崎付近（測線M-3〜M-6の南側）の 西向きの流れとなっている. 冬季観測でも，満潮時に北 側湾口の測線1-9で水俣湾に流入する流れが確認されて いる. 下げ潮最強時に対応する2回目（図-6 (b) 参照) で は，海水が西側湾口の測線M-1から八代海へ流出してい る. とくに, 湾中央部付近に着目すると, 冬季観測時に は確認されなかった比較的大きな時計回りの地形性渦が 認められる.さらに，上げ潮最強時に近い 4 回目 (図6 (d) 参照) の結果からは, 西側湾口M-1上の表層で八代海 から湾内へ流入する流れが生じている．流入した海水は 湾全体に拡がりながら，南側湾口のM-10より袋浦へ，北 側湾口のM-9から八代海へ流出していることも分かる.

\section{b) 流速ベクトルの鉛直分布}

図-7 (a)〜 (e) は，それぞれ測線M-4，M-1，M-9，M-10 およびF-1上で計測された流速ベクトルの鉛直分布であ
る. 図-7 (a) は, 図-6 (b) で明らかとなった時計回りの地 形性渦の流動構造を測線M-4の鉛直断面内で表示したも のである. 時計回りの地形性渦は水深の増加とともに弱 化傾向にあるものの，少なくとも水深7mまでは存在して いることが分かる．図-7 (b)〜 (e) は，水俣湾全域の表層 で東向きの流れが卓越した上げ潮最強時付近の流速べク トルの鉛直分布図であり，それぞれ測線M-1，M-9，M-10 およびF-1に対応している. 図-6 (d) で見られたM-1上で の強い東向きの流れは, 水深5〜 6m付近を境に逆向きと なっている（図-7 (b) 参照）。これは，干潮時から上げ 潮最強時にかけて八代海周辺で連吹していた南西の風3 〜 $\mathrm{m} / \mathrm{s}$ (図-2最下図参照) の影響による吹送流と判断され る. さらに, 図-7 (c) からは北側湾口M-9の水深 $2 \sim 4 m に$ 八代海へ流出する流れが見られる。一方, 航行距離が 125 200mの恋路島側では, 水深4m以下で流れが表層と は逆向きとなっており，地形性の反流と推測される．ま た, 袋浦の湾口M-10（図-7 (d) 参照）では，表層から水 深5mまでに流れが集中して袋浦へ流入している. その後, 流れは平面的な地形の影響を受けて袋浦の東側を回り込 むように浦奥へと流れ込んでいることが分かる（図7 (e) および図-6 (d) 中の破線棈円部を参照) 。 


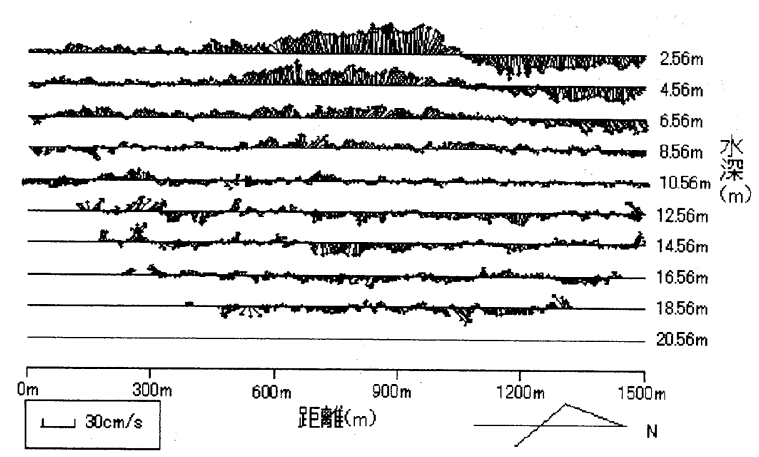

（a）2回目 (下げ潮最強時付近)，観測線M-4

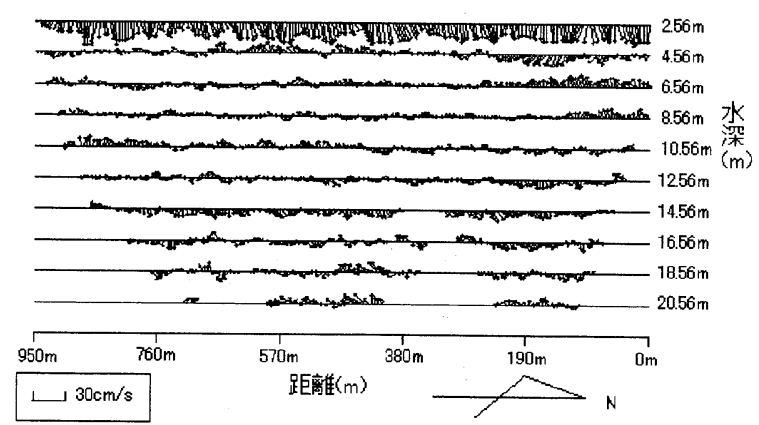

(b) 4回目 (上げ潮最強時付近)，観測線M-1

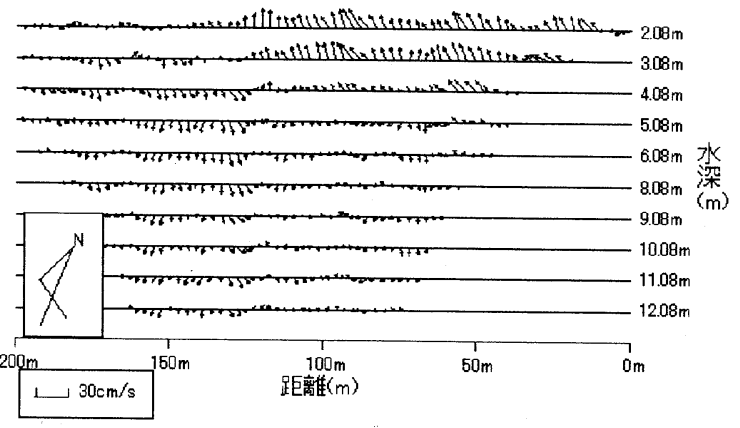

（c） 4 回目 (上げ潮最強時付近)，観測線M-9



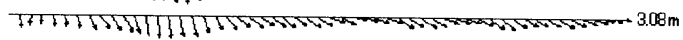

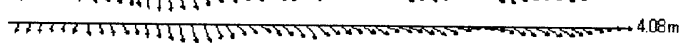

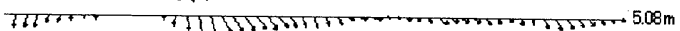

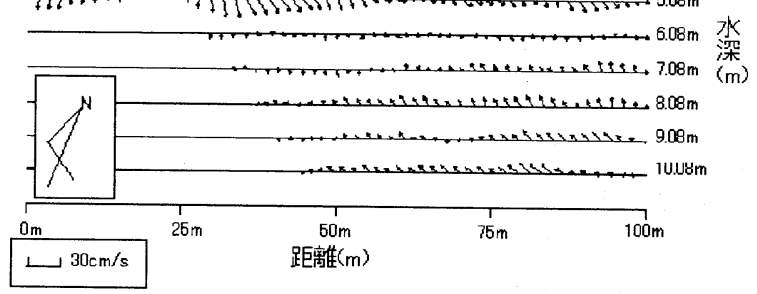

（d） 4 回目 (上げ潮最強時付近)，観測線M-10

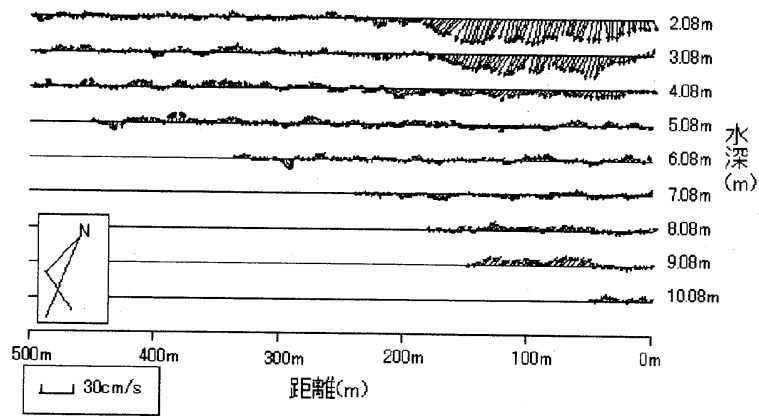

(e) 4回目 (上げ潮最強時付近)，観測線F-1

図-7 流速ベクトルの鉛直分布
$Q ;\left(\mathrm{m}^{3} / \mathrm{s}\right)$ 流入流量



$Q\left(\mathrm{~m}^{3} / \mathrm{s}\right)$ 流入流量
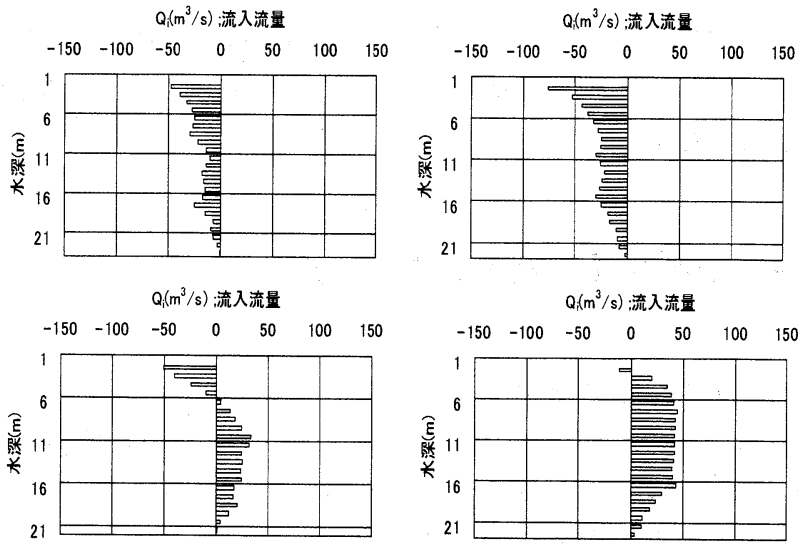

$Q:\left(\mathrm{m}^{3} / \mathrm{s}\right)$ 流入流量

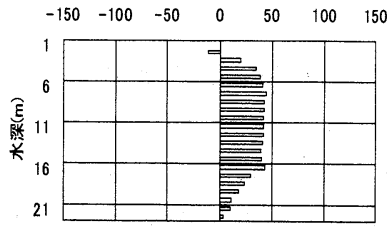

（a）冬季循環期における通過流量の鈆直分布 (左上 : 満潮時, 右上 : 下げ潮最強時, 左下 : 干潮時, 右下 : 上げ潮最強時)
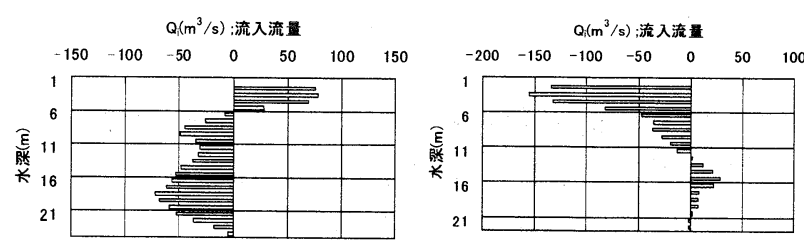

$\mathrm{Q}\left(\mathrm{m}^{3} / \mathrm{s}\right)$; 流入流量

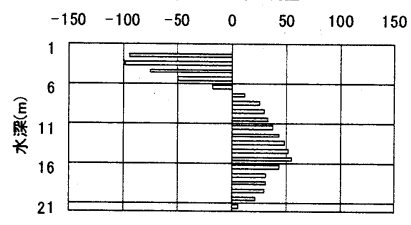

$\mathrm{Q}\left(\mathrm{m}^{3} / \mathrm{s}\right)$ 流入流量

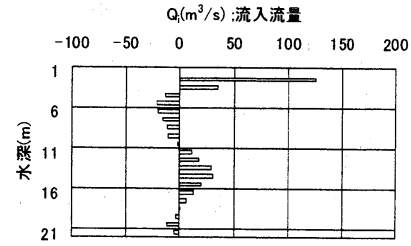

(b) 夏季成層期における通過流量の鉛直分布 (左上 : 満潮時付近, 右上 : 下げ潮最強時付近, 左下 : 干潮時付近, 右下 : 上げ潮最強時付近)

図-8 西側湾口M-1断面を通過する流量の鈶直分布

\section{（3）西側湾口M-1断面を通過する流量の鉛直分布}

冬季の観測結果に基づけば，西側湾口M-1の鈶直断面 で生じる流れは，水俣湾の海水交換に著しく影響を及ぼ していることが明らかとなった，そこで，冬季および夏 季のM-1の鉛淔断面上で計測されたADCPの流速データか ら水深 $1 \mathrm{~m}$ 毎の通過流量; $Q_{i}\left(\mathrm{~m}^{3} / \mathrm{s}\right)$ を算定し, その鉛直分 布を示したものが図-8である. 図中の縦軸は水深，横軸 は水深 $1 \mathrm{~m}$ 毎の鉛直断面を通過する流量である．流量が正 の場合には，流れが水俣湾へ流入している。図-8 (a) に 示す冬季の結果から，満潮時，下げ潮最強時，上げ潮最 強時のいずれも $50 \mathrm{~m}^{3} / \mathrm{s}$ 以下の值で，全水深に渡って同一 の方向に流動していることが確認できる. 一方，干潮時 には水深 $6 m$ 付近で流れが反転している.この原因は，表 層の流れが北東よりの風の影響を，水深 $6 \mathrm{~m} よ り$ 深いとこ ろの流れが潮汐の影響を受けていたためと考えられる. さらに，夏季の結果（図-8 (b) 参照) では，水深6〜8mを 境に流入と流出が逆転した分布となっている. とくに, 満潮時付近や干潮時付近の結果からは, 水深 $6 \mathrm{~m}$ 以下の 
中・底層に最大 $50 \mathrm{~m}^{3} / \mathrm{s}$ 超える表層と逆向きの流れが存 在していることや，底層の通過流量は表層の通過流量に ほぼ匹敵していることも明らかとなった.

\section{4. 成層調査の結果および考察}

\section{（1）水温の鉛直分布}

図-9は，冬季 (2002年12月2日) と夏季 (2003年7月29日) に測線M-1の中央に位置する観測点 $\mathrm{f}$ で計測された水温の 鉛直分布図である．冬季は全水深に渡って混合状態と なっており，水温成層は認められない，一方，夏季の結

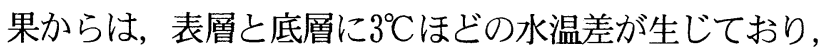
水深 $4 \mathrm{~m} \sim 8 \mathrm{~m}$ に水温躍層の形成が確認される. 図-8 (b) で 明らかとなった流れの逆転が生じている水深と水温躍層 の水深がほぼ一致することも認められる.

\section{（2）夏季観測から得られた水温分布の時間的変化}

横軸を潮汐の状態, 縦軸を海底からの水位と設定して, 観測点 $\mathrm{f}$ 夏季に観測された水温のイソプレットを図-10 に示す. 下げ潮最強時から干潮時の間で $24.5^{\circ} \mathrm{C} \sim 27.5^{\circ} \mathrm{C}$ の等温線が密に収束している.これは, 気温の上昇ととも に水温躍層が発達したものと解釈される. なお, 図中の 太線は海水面を表している.

さらに, 図-11は, 西側湾口の測線M-1と直交する鉛直 断面（観測点e, $\mathrm{f}, \mathrm{g}$ を結んだ鉛直断面）内の水温分布 の時間的変化を示したものである. 満潮時には水深3〜

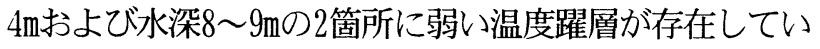
る.これらは, 時間の経過とともに発達し, 干潮時の水深 5〜6mに認められる強い水温躍層となっている.なお, 既 述した上げ潮最強時付近の表層における流れの反転

（図-7 (b) 参照）はこの躍層を境しして生じている.

\section{5. まとめ}

水俣湾の流動特性を解明するため, 冬季と夏季の2回に 渡って現地観測を実施した. その結果, 冬季循環期には, 潮汐に追随した流れが西側湾口のM-1断面で確認できた. 夏季の観測結果からは，下け潮最強時付近で湾中央部に 時計回りの地形性渦の発生が明らかとなった. さらに, 西側湾口のM-1断面で生じる流れは，水俣湾の海水交換 に著しく影響を及ぼしていることも明らかとなった.

\section{参考文献}

1) Tomiyasu, T., A. Nagano, N. Yonehara, H. Sakamoto, Rifardi, K. Oki and H. Akagi (2000) : Mercury contaminant in the Yatsushiro Sea, south-western Japan: spatial variations of mercury in sediment, Sci. Total Environ., Vol.257, pp.121-132.

2) 大木公彦, 内田かおり, 入江美晴(2001): 水俣湾沖の水銀
污染と底生有孔虫群集の垂直変化, 月刊海洋, Vol. 33, №. 6, pp. 414-419.

3) ht tp://www. n-bcom. co.jp/tsuji/fishing/salt/

4) ht tp://fukuoka-jma. go. jp/kumamoto/ (2004 9. 30受付)



(a) 冬季に観測された水温分布

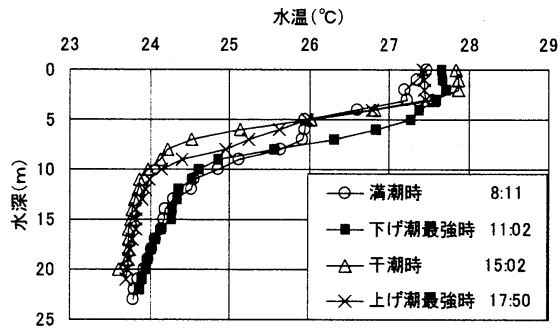

(b) 夏季に観測された水温分布

図-9 観測点 $f$ の水温の鉛直分布



図-10 観測点fの時間変化を表す水温のイソプレット

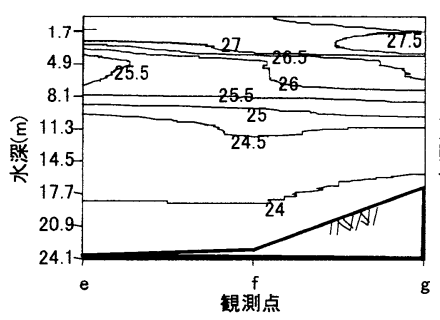

(a) 満潮時付近

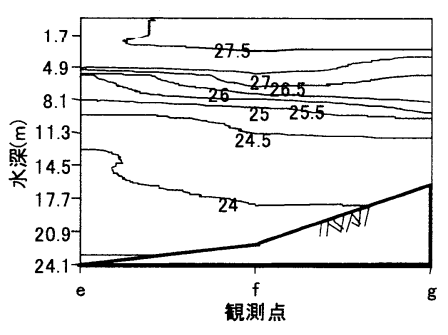

(b) 下げ潮最強時付近

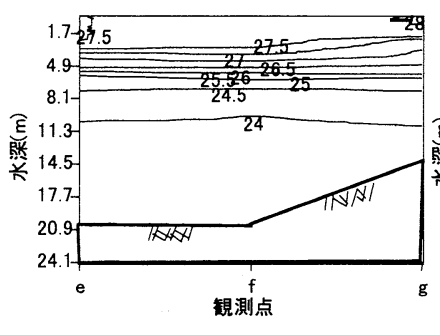

(c) 干潮時付近



（d）上げ潮最強時付近
図-11 夏季観測で得られた観測点e, f, gを結んだ鉛直 断面内での水温分布の時間変化

(2004.9.30 受付) 